\title{
BRF1 wt Allele
}

National Cancer Institute

\section{Source}

National Cancer Institute. BRF1 wt Allele. NCI Thesaurus. Code C52625.

Human BRF1 wild-type allele is located in the vicinity of $14 q$ and is approximately $92 \mathrm{~kb}$ in length. This allele, which encodes transcription factor IIIB $90 \mathrm{kDa}$ subunit protein, plays a role in the transcriptional initiation of small RNA species. 